\title{
Reanalysis of Cost and Moist Air Oxidation Performance for CF8C-Plus and Other Alloys for AUSC Applications
}
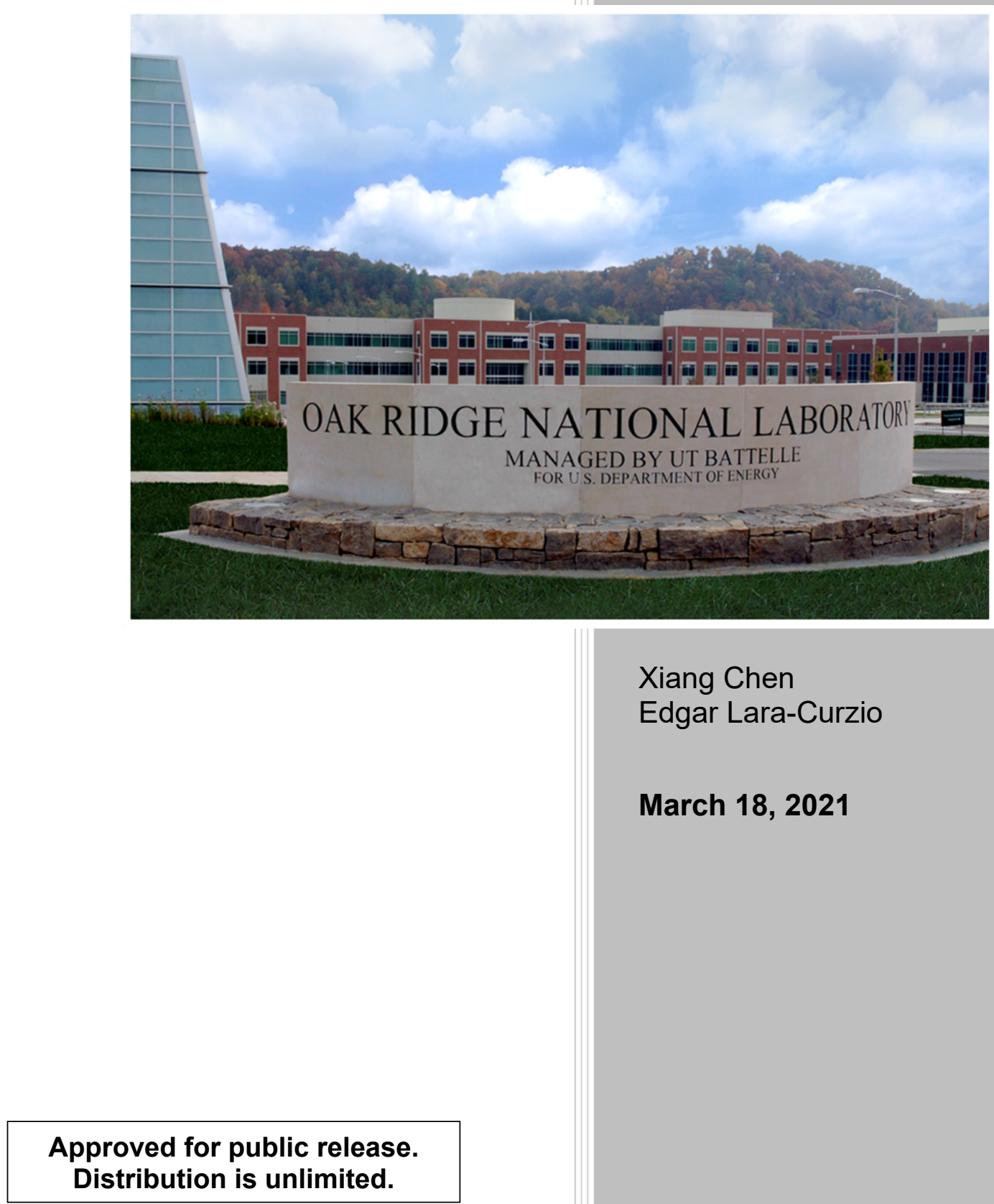

Xiang Chen

Edgar Lara-Curzio

March 18, 2021 


\title{
DOCUMENT AVAILABILITY
}

Reports produced after January 1, 1996, are generally available free via US Department of Energy (DOE) SciTech Connect.

Website www.osti.gov

Reports produced before January 1, 1996, may be purchased by members of the public from the following source:

\author{
National Technical Information Service \\ 5285 Port Royal Road \\ Springfield, VA 22161 \\ Telephone 703-605-6000 (1-800-553-6847) \\ TDD 703-487-4639 \\ Fax 703-605-6900 \\ E-mail info@ntis.gov \\ Website http://classic.ntis.gov/
}

Reports are available to DOE employees, DOE contractors, Energy Technology Data Exchange representatives, and International Nuclear Information System representatives from the following source:

Office of Scientific and Technical Information

PO Box 62

Oak Ridge, TN 37831

Telephone 865-576-8401

Fax 865-576-5728

E-mail reports@osti.gov

Website http://www.osti.gov/contact.html

This report was prepared as an account of work sponsored by an agency of the United States Government. Neither the United States Government nor any agency thereof, nor any of their employees, makes any warranty, express or implied, or assumes any legal liability or responsibility for the accuracy, completeness, or usefulness of any information, apparatus, product, or process disclosed, or represents that its use would not infringe privately owned rights. Reference herein to any specific commercial product, process, or service by trade name, trademark, manufacturer, or otherwise, does not necessarily constitute or imply its endorsement, recommendation, or favoring by the United States Government or any agency thereof. The views and opinions of authors expressed herein do not necessarily state or reflect those of the United States Government or any agency thereof. 
Materials Science and Technology Division

\section{REANALYSIS OF COST AND MOIST AIR OXIDATION PERFORMANCE FOR CF8C-PLUS AND OTHER ALLOYS FOR AUSC APPLICATIONS}

Xiang Chen and Edgar Lara-Curzio

Date Published:

March 18, 2021

Prepared by

OAK RIDGE NATIONAL LABORATORY

Oak Ridge, TN 37831-6283

managed by

UT-BATTELLE, LLC

for the

US DEPARTMENT OF ENERGY

under contract DE-AC05-00OR22725 



\section{TABLE OF CONTENTS}

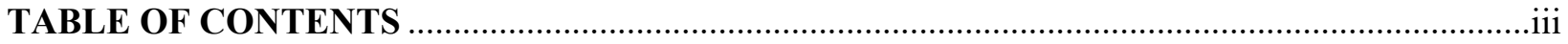

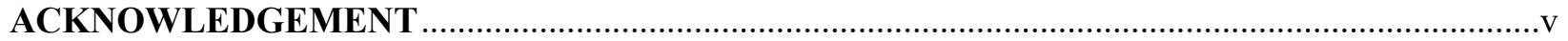

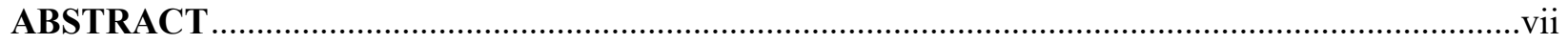

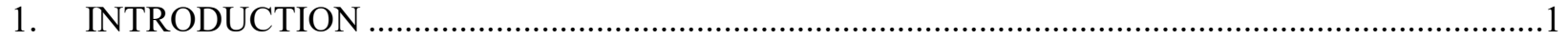

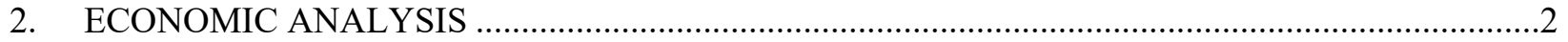

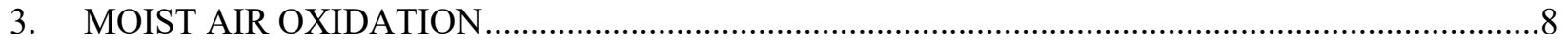

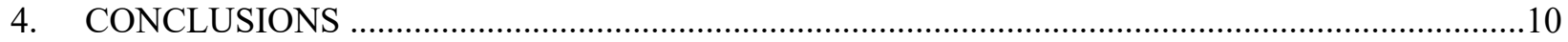

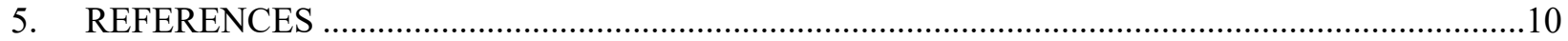




\section{ACKNOWLEDGEMENT}

This project is sponsored by the U.S. DOE, Office of Fossil Energy, High Performance Materials, under contract DE-AC05-00OR22725 with ORNL managed by UT Battelle, LLC. We are grateful to M.

Fasouletos (NETL) for the programmatic support. We also would like to V. Cedro III (NETL) for helpful discussion during the preparation of this report and S. Dryepondt (ORNL) for his technical review of this report. 


\begin{abstract}
This report provides an economic analysis of CF8C-Plus and other candidate materials for Advanced Ultra Supercritical (AUSC) applications, including 347HFG, HR6W, Sanicro 25, Super 304H, Grade 92, SAVE12AD, Inconel 617, and Inconel 740H. An assessment of their moist air oxidation performance is also included. When compared with the aforementioned alloys, CF8C-Plus shows a favorable balance between cost, creep strength and moist air oxidation resistance in the temperature range of $600-700^{\circ} \mathrm{C}$. Furthermore, its castability makes it additionally attractive from a manufacturing perspective. Materials with higher Ni content, such as HR6W, Sanicro 25, Inconel 617, and Inconel 740H, have better creep strength but the improved performance comes with increased cost. Stainless steel 347HFG exhibits inferior creep strength and lower moist air oxidation resistance, but at a greater cost, compared with CF8C-Plus. Super 304H, another stainless steel, has similar creep strength and cost compared to CF8CPlus at $700^{\circ} \mathrm{C}$, but may not have as good moist air oxidation resistance. Grade 92 has lower creep strength and unfavorable economy compared with CF8C-Plus. SAVE12AD also has lower creep strength than CF8C-Plus, but has lower cost to use at $600^{\circ} \mathrm{C}$. Both Grade 92 and SAVE12AD are also limited to the maximum use temperature of $649^{\circ} \mathrm{C}$ per ASME code case requirements.
\end{abstract}




\section{INTRODUCTION}

Advanced Ultra Supercritical (AUSC) power plants combine dual benefits of higher operation efficiency and reduced $\mathrm{CO}_{2}$ emissions. However, the operating conditions of AUSC power plants, such as steam temperatures up to $760^{\circ} \mathrm{C}$ and pressures in excess of 3,000 psi, also impose tremendous challenges on existing materials for coal-based power plants. In this report, we performed a cost analysis and an assessment of moist air oxidation rate for CF8C-Plus, and other AUCS candidate materials, i.e. 347HFG, HR6W, Sanicro ${ }^{\circledR}$ 25, Super 304H, Grade 92, SAVE12AD, Inconel ${ }^{\circledR} 617$, and Inconel ${ }^{\circledR} 740 \mathrm{H}^{\circledR}$, in the temperature range of $600-760^{\circ} \mathrm{C}$. The nominal compositions of the alloys investigated in this study are listed in Table 1.

Table 1 Composition of studied materials for AUSC application (wt\%) [1-8]

\begin{tabular}{|c|c|c|c|c|c|c|c|c|c|c|c|}
\hline & C & $\mathrm{Si}$ & $\mathrm{Mn}$ & $\mathrm{Cr}$ & $\mathrm{Cu}$ & $\mathrm{Ni}$ & $\mathrm{Nb}$ & $\mathrm{N}$ & B & $\mathrm{Fe}$ & Other \\
\hline $\begin{array}{l}\text { CF8C- } \\
\text { Plus }\end{array}$ & 0.1 & 0.5 & 4.0 & 19 & - & 12.5 & 0.8 & 0.25 & - & Bal & $0.3 \mathrm{Mo}$ \\
\hline 347HFG & $\begin{array}{l}0.06 \\
-0.1\end{array}$ & $<0.75$ & $<2$ & $\begin{array}{l}17- \\
20\end{array}$ & - & $9-13$ & $<1$ & - & - & Bal & - \\
\hline HR6W & $<0.1$ & $<1$ & $<1.5$ & $\begin{array}{l}21.5- \\
24.5\end{array}$ & - & Bal & $\begin{array}{l}0.1- \\
0.35\end{array}$ & $<0.02$ & $\begin{array}{l}5-60 \\
\mathrm{ppm}\end{array}$ & $\begin{array}{l}20- \\
27\end{array}$ & $\begin{array}{c}\text { 6-8 W, } 0.05-0.2 \\
\mathrm{Ti}\end{array}$ \\
\hline $\begin{array}{c}\text { Sanicro } \\
25\end{array}$ & $\leq 0.1$ & 0.2 & 0.5 & 22.5 & 3 & 25 & 0.5 & 0.23 & - & Bal & $3.6 \mathrm{~W}, 1.5 \mathrm{Co}$ \\
\hline $\begin{array}{l}\text { Super } \\
304 \mathrm{H}\end{array}$ & $\begin{array}{c}0.07 \\
- \\
0.13\end{array}$ & $<0.3$ & $<1$ & $\begin{array}{l}17- \\
19\end{array}$ & $\begin{array}{l}2.5- \\
3.5\end{array}$ & $\begin{array}{l}7.5- \\
10.5\end{array}$ & $\begin{array}{l}0.3- \\
0.6\end{array}$ & $\begin{array}{c}0.05- \\
0.12\end{array}$ & - & Bal & - \\
\hline $\begin{array}{c}\text { Grade } \\
92\end{array}$ & $\begin{array}{c}0.07 \\
- \\
0.13\end{array}$ & 0.5 & $\begin{array}{l}0.3- \\
0.6\end{array}$ & $\begin{array}{l}8.5- \\
9.5\end{array}$ & - & 0.4 & $\begin{array}{c}0.04 \\
- \\
0.09\end{array}$ & $\begin{array}{l}0.03- \\
0.07\end{array}$ & $\begin{array}{c}10- \\
60 \\
\mathrm{ppm}\end{array}$ & Bal & $\begin{array}{c}0.3-0.6 \mathrm{Mo} \\
0.15-0.25 \mathrm{~V} \\
1.5-2.0 \mathrm{~W}\end{array}$ \\
\hline $\begin{array}{l}\text { SAVE12 } \\
\text { AD }\end{array}$ & $\begin{array}{l}0.05 \\
- \\
0.10\end{array}$ & $\begin{array}{l}0.05- \\
0.50\end{array}$ & $\begin{array}{l}0.2- \\
0.7\end{array}$ & $\begin{array}{l}8.5- \\
9.5\end{array}$ & - & $<0.2$ & $\begin{array}{l}0.05 \\
- \\
0.12\end{array}$ & $\begin{array}{l}0.005- \\
0.015\end{array}$ & $\begin{array}{l}70- \\
150 \\
\mathrm{ppm}\end{array}$ & Bal & $\begin{array}{c}2.5-3.5 \mathrm{~W}, 2.5- \\
3.5 \mathrm{Co}, 0.15- \\
0.3 \mathrm{~V}, 0.01- \\
0.06 \mathrm{Nd}, 0.05- \\
0.12 \mathrm{Nb}+\mathrm{Ta}\end{array}$ \\
\hline $\begin{array}{c}\text { Inconel } \\
617\end{array}$ & $\begin{array}{c}0.05 \\
- \\
0.15\end{array}$ & $<1$ & $<1$ & $\begin{array}{l}20- \\
24\end{array}$ & $<0.5$ & Bal & - & - & $\begin{array}{l}<60 \\
\text { ppm }\end{array}$ & $<3$ & $\begin{array}{c}10-15 \mathrm{Co}, 0.8- \\
1.5 \mathrm{Al}, 8-10 \\
\mathrm{Mo},<0.6 \mathrm{Ti}\end{array}$ \\
\hline $\begin{array}{c}\text { Inconel } \\
740 \mathrm{H}\end{array}$ & 0.03 & 0.15 & $<1$ & 24.5 & $<0.5$ & Bal & 1.5 & - & $\begin{array}{l}\text { 6-60 } \\
\text { ppm }\end{array}$ & $<3$ & $\begin{array}{l}20 \mathrm{Co}, 1.35 \mathrm{Al}, \\
0.1 \mathrm{Mo}, 1.35 \mathrm{Ti}\end{array}$ \\
\hline
\end{tabular}




\section{ECONOMIC ANALYSIS}

A cost analysis was performed assuming the candidate materials would be used to manufacture 2-inch OD tubes or 12-inch ID pipes and would have to withstand a design steam pressure of $24 \mathrm{MPa}$ at temperatures between $600^{\circ} \mathrm{C}$ and $700^{\circ} \mathrm{C}$. Table 2 lists the material properties and cost information. Following the analysis of Li, Cedro and Conrad [10], it was assumed that the 12-inch ID pipe has a $\$ 5 / \mathrm{lbs}$ premium over the 2-inch OD tube for the Fe-based austenitic steels and a $\$ 10 / \mathrm{lbs}$ premium for the Nibased alloys and high $\mathrm{W}$ alloys. It is also worth noting that for Grade 92 and SAVE12AD, the maximum use temperature is $649^{\circ} \mathrm{C}$ from ASME code case 2179 and 2839 , respectively. The allowable stress values at $650^{\circ} \mathrm{C}$ in Table 2 for these two materials are provided for interpolation purposes only.

Table 2. Density, ASME allowable stress, and pricing information of studied materials

\begin{tabular}{|c|c|c|c|c|c|c|c|}
\hline & \multirow{2}{*}{$\begin{array}{l}\text { Density } \\
\left(\text { lbs/in }^{3}\right)\end{array}$} & \multicolumn{3}{|c|}{$\begin{array}{l}\text { ASME allowable stress* } \\
\text { (MPa) }\end{array}$} & \multirow{2}{*}{$\begin{array}{c}\text { Raw material } \\
\text { price** } \\
(\$ / \text { lbs })\end{array}$} & \multicolumn{2}{|c|}{$\begin{array}{l}\text { Price of tube or pipe }{ }^{* \star *} \\
\text { (\$/lbs) }\end{array}$} \\
\hline & & $600^{\circ} \mathrm{C}$ & $650^{\circ} \mathrm{C}$ & $700^{\circ} \mathrm{C}$ & & $\begin{array}{l}\text { 2-inch OD } \\
\text { tube }\end{array}$ & $\begin{array}{l}\text { 12-inch ID } \\
\text { pipe }\end{array}$ \\
\hline CF8C-Plus & 0.282 & 108.20 & 74.30 & 50.20 & 1.02 & 4.73 & 9.73 \\
\hline 347HFG & 0.288 & 87.95 & 66.90 & 39.14 & 1.48 & 3.73 & 8.73 \\
\hline HR6W & 0.306 & 103.00 & 80.60 & 58.40 & 2.77 & 23 & 33 \\
\hline Sanicro 25 & 0.290 & 122.00 & 111.00 & 64.40 & 1.94 & 20 & 25 \\
\hline Super $304 \mathrm{H}$ & 0.285 & 92.30 & 78.00 & 46.90 & 0.74 & $\begin{array}{l}4.22(\min ) \\
8(\max )\end{array}$ & $\begin{array}{l}9.22(\min ) \\
13(\max )\end{array}$ \\
\hline Grade 92 & 0.29 & 77.0 & 38.3 & - & 0.23 & 3.26 & 8.26 \\
\hline SAVE12AD & 0.285 & 103 & 44 & - & 0.85 & 3.39 & 8.39 \\
\hline Inconel 617 & 0.302 & 106.01 & 105.49 & 80.86 & 5.58 & 33 & 43 \\
\hline $\begin{array}{c}\text { Inconel } \\
740 \mathrm{H}\end{array}$ & 0.291 & 274.00 & 226.00 & 146.00 & 5.96 & 47 & 57 \\
\hline
\end{tabular}

*For CF8C-Plus, ASME allowable stress is from [9] and for remaining materials, ASME allowable stresses are from [10]

**Based on CY 2015 alloy ingredient price from [10]

$* * *$ For CF8C-Plus, price is from [11] and for remaining materials, prices are from [12] except for $347 \mathrm{HFG}$ from [13] and Super 304H from [13] and [14] 
The thickness of the 2-inch OD tube or 12-inch ID pipe needed to withstand the steam pressure at temperature is calculated using the same practice as in [10], which is based on ASME Boiler and Pressure Vessel Code Section I Appendix A-317 "Cylindrical Components under Internal Pressure." According to this analysis, the equations to calculate the 2-inch OD tube and 12-inch ID pipe thicknesses are given by:

$$
t_{\text {tube }}=\frac{D_{0}\left(1-e^{-P / S E}\right)}{2}+C+F
$$

where:

$\mathrm{D}_{0}=$ outside diameter (inch),

$\mathrm{P}=$ design pressure $(\mathrm{MPa})$,

$\mathrm{S}=$ ASME allowable stress,

$\mathrm{E}=$ efficiency (assumed to be 1),

$\mathrm{C}=$ allowance for threading (assumed to be 0 ),

$\mathrm{F}=$ allowance for expanding (assumed to be 0 ).

$$
t_{\text {pipe }}=\frac{D_{i}\left(e^{P / S E}-1\right)}{2}+C+F
$$

where:

$\mathrm{D}_{\mathrm{i}}=$ inside diameter (inch),

$\mathrm{P}=$ design pressure $(\mathrm{MPa})$,

$\mathrm{S}=$ ASME allowable stress,

$\mathrm{E}=$ efficiency (assumed to be 1),

$\mathrm{C}=$ allowance for threading (assumed to be 0 ),

$\mathrm{F}=$ allowance for expanding (assumed to be 0 ).

The resulting thickness values of the studied materials are shown in Table 3. In general, CF8C-Plus has a thinner wall thickness than 9Cr steels, such as Grade 92 and SAVE12AD, and the other two austenitic stainless steels, $347 \mathrm{HFG}$ and Super $304 \mathrm{H}$, but has a thicker wall compared with materials with higher Ni contents, i.e. HR6W, Sanicro 25, Inconel 617 and Inconel 740H. The thickness values of the studied materials are further illustrated in Fig. 1 for $650^{\circ} \mathrm{C}$. Compared with other AUSC candidate materials, tubes and pipes made from Grade 92 and SAVE12AD need much thicker wall due to significantly lower ASME allowable stress for both materials at $650^{\circ} \mathrm{C}$.

Combining the material volume, density, and pricing data, we calculated the unit price among AUSC candidate materials for 2-inch OD tube and 12-inch ID pipe as well as 2-inch OD tube usable volume (open volume inside the tube) per dollar. The results are summarized in Table 4 and further illustrated in Fig. 2. Overall, CF8C-Plus exhibited impressive economical advantage over other materials except for the 2-inch OD tube form where 347HFG and Super 304H at the minimum price case show similar economy as compared with CF8C-Plus. In addition, SAVE12AD also indicates better economy over CF8C-Plus for the 2-inch OD tube and 12-inch ID pipe applications at $600^{\circ} \mathrm{C}$ 
Table 3 Thickness of studied materials for AUCS applications

\begin{tabular}{|c|c|c|c|c|c|c|}
\hline \multirow{2}{*}{} & \multicolumn{5}{|l|}{ 2-inch OD tube thickness (inch) } & \multicolumn{3}{l}{ 12-inch ID pipe thickness (inch) } \\
\cline { 2 - 7 } & $600^{\circ} \mathrm{C}$ & $650^{\circ} \mathrm{C}$ & $700^{\circ} \mathrm{C}$ & $600^{\circ} \mathrm{C}$ & $650^{\circ} \mathrm{C}$ & $700^{\circ} \mathrm{C}$ \\
\hline CF8C-Plus & 0.200 & 0.277 & 0.382 & 1.499 & 2.303 & 3.703 \\
\hline 347HFG & 0.240 & 0.303 & 0.460 & 1.894 & 2.606 & 5.115 \\
\hline HR6W & 0.209 & 0.259 & 0.338 & 1.584 & 2.094 & 3.070 \\
\hline Sanicro 25 & 0.179 & 0.195 & 0.313 & 1.312 & 1.457 & 2.728 \\
\hline Super 304H & 0.230 & 0.266 & 0.402 & 1.793 & 2.176 & 4.037 \\
\hline Grade 92 & 0.268 & 0.466 & - & 2.194 & 5.228 & - \\
\hline SAVE12AD & 0.208 & 0.420 & - & 1.574 & 4.352 & - \\
\hline Inconel 617 & 0.203 & 0.203 & 0.257 & 1.524 & 1.533 & 2.073 \\
\hline Inconel 740H & 0.084 & 0.101 & 0.152 & 0.549 & 0.672 & 1.072 \\
\hline
\end{tabular}




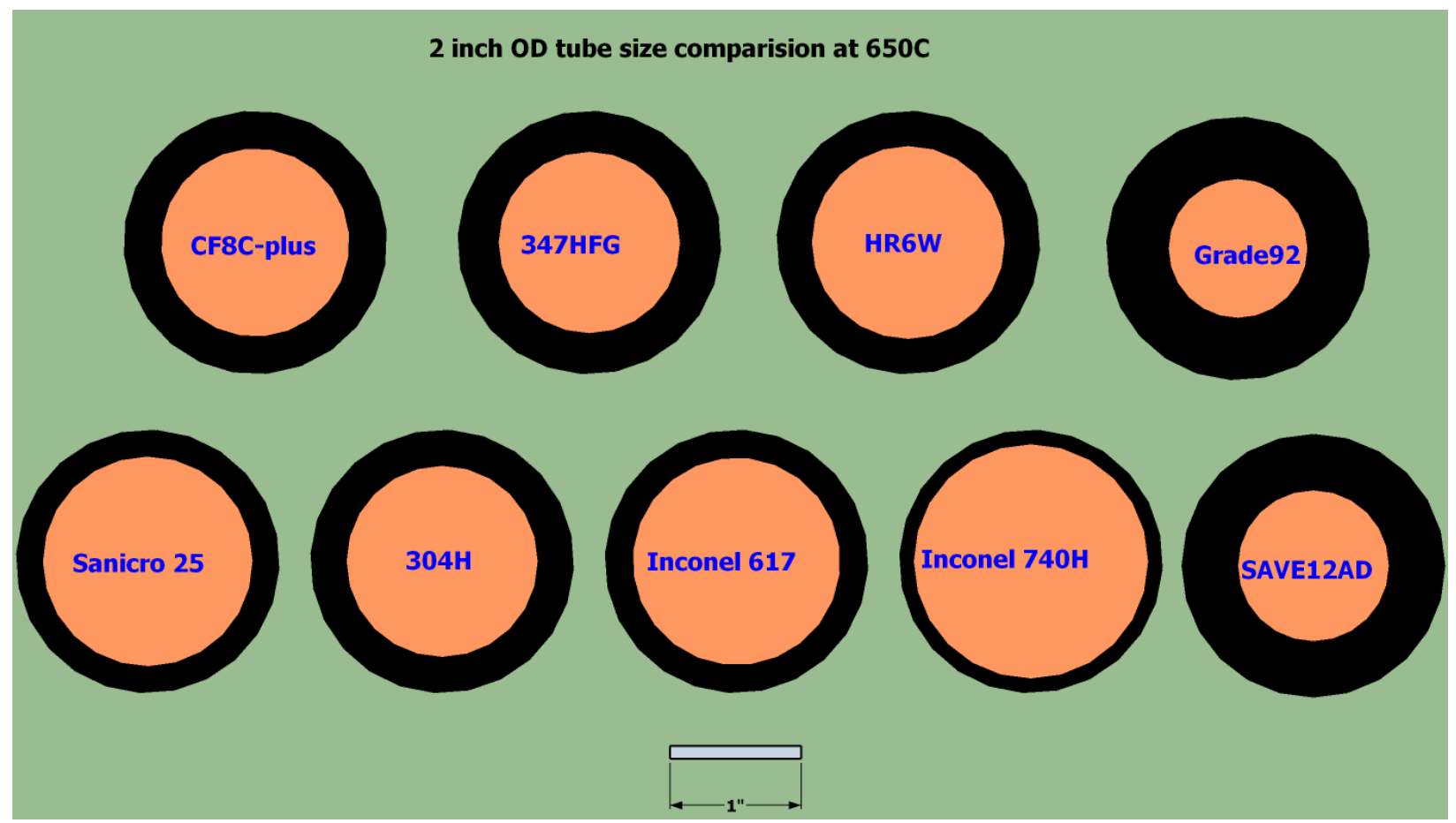

(a)

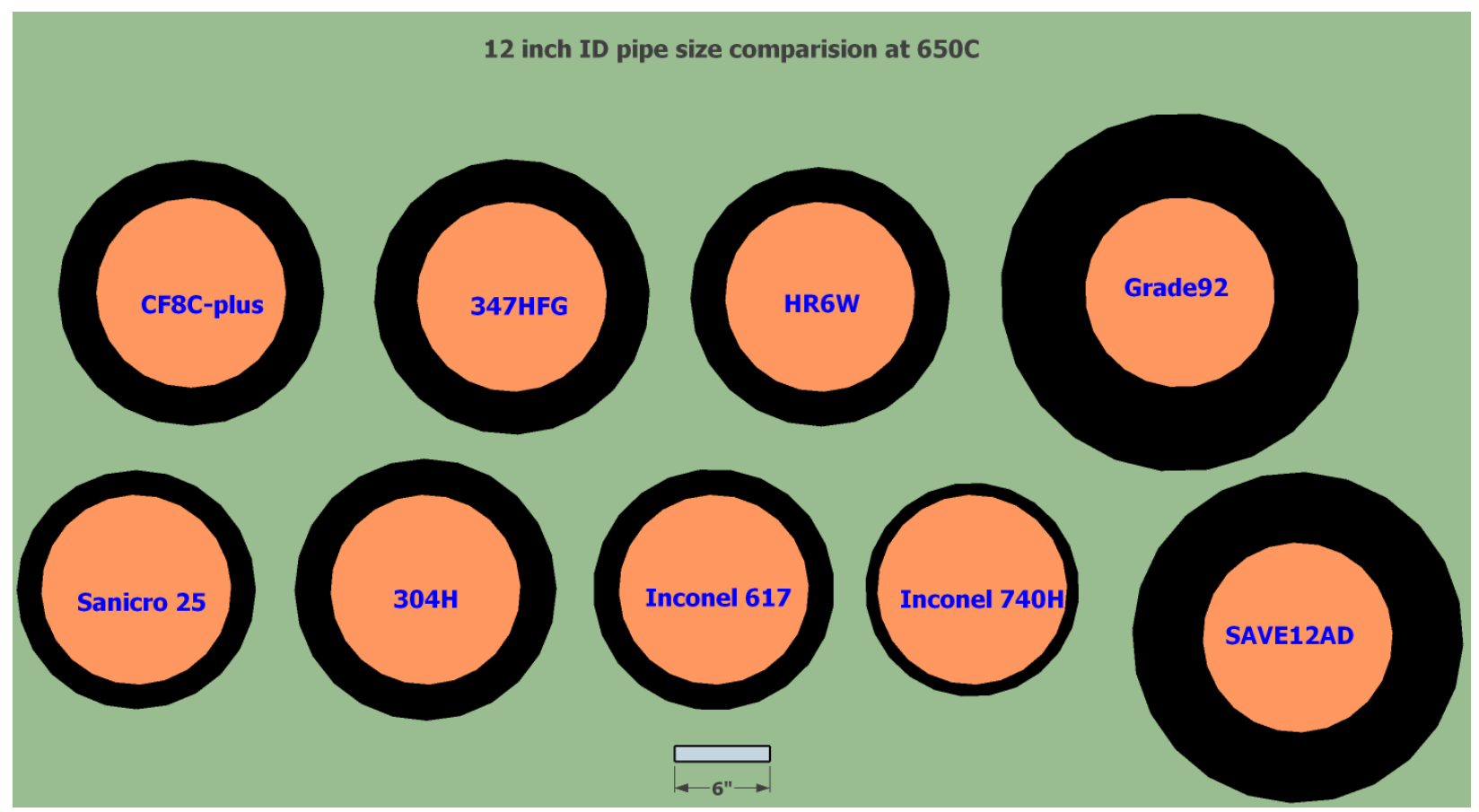

(b)

Fig. 1 Size comparison for AUSC candidate materials for (a) 2-inch OD tube and (b) 12-inch ID pipe 
Table 4 Economical analysis of studied materials for AUCS applications

\begin{tabular}{|c|c|c|c|c|c|c|c|c|c|}
\hline & \multicolumn{3}{|c|}{ 2-inch OD tube price $(\$ / \mathrm{ft})$} & \multicolumn{3}{|c|}{ 2-inch OD tube usable volume (in $3 / \$$ ) } & \multicolumn{3}{|c|}{ 12-inch ID pipe price $(\$ / f t)$} \\
\hline & $600^{\circ} \mathrm{C}$ & $650^{\circ} \mathrm{C}$ & $700^{\circ} \mathrm{C}$ & $600^{\circ} \mathrm{C}$ & $650^{\circ} \mathrm{C}$ & $700^{\circ} \mathrm{C}$ & $600^{\circ} \mathrm{C}$ & $650^{\circ} \mathrm{C}$ & $700^{\circ} \mathrm{C}$ \\
\hline $\begin{array}{l}\text { CF8C- } \\
\text { Plus }\end{array}$ & 18 & 24 & 31 & 1.33 & 0.82 & 0.46 & 2092 & 3404 & 6012 \\
\hline $347 \mathrm{HFG}$ & 17 & 21 & 29 & 1.27 & 0.88 & 0.38 & 2495 & 3608 & 8299 \\
\hline HR6W & 99 & 120 & 149 & 0.24 & 0.17 & 0.11 & 8192 & 11237 & 17613 \\
\hline $\begin{array}{c}\text { Sanicro } \\
25\end{array}$ & 71 & 77 & 115 & 0.36 & 0.32 & 0.15 & 4775 & 5359 & 10979 \\
\hline $\begin{array}{l}\text { Super } \\
304 \mathrm{H}\end{array}$ & $\begin{array}{c}19(\min ) \\
35(\max )\end{array}$ & $\begin{array}{l}21(\min ) \\
40(\max )\end{array}$ & $\begin{array}{l}29(\min ) \\
55(\max )\end{array}$ & $\begin{array}{l}1.21(\min ) \\
0.64(\max )\end{array}$ & $\begin{array}{l}0.97(\min ) \\
0.51(\max )\end{array}$ & $\begin{array}{l}0.46(\min ) \\
0.24(\max )\end{array}$ & $\begin{array}{c}2450 \text { (min) } \\
3454 \text { (max) }\end{array}$ & $\begin{array}{c}3055 \text { (min) } \\
4308 \text { (max) }\end{array}$ & $\begin{array}{l}\text { 6414(min) } \\
9044(\max )\end{array}$ \\
\hline Grade 92 & 16.5 & 25.5 & - & 1.22 & 0.42 & - & 2813 & 8133 & - \\
\hline $\begin{array}{c}\text { SAVE12 } \\
\text { AD }\end{array}$ & 13.6 & 24.2 & - & 1.74 & 0.52 & - & 1926 & 6416 & - \\
\hline $\begin{array}{c}\text { Inconel } \\
617\end{array}$ & 137 & 137 & 168 & 0.18 & 0.17 & 0.12 & 10093 & 10155 & 14285 \\
\hline $\begin{array}{c}\text { Inconel } \\
740 \mathrm{H}\end{array}$ & 83 & 99 & 144 & 0.38 & 0.31 & 0.19 & 4310 & 5327 & 8763 \\
\hline
\end{tabular}

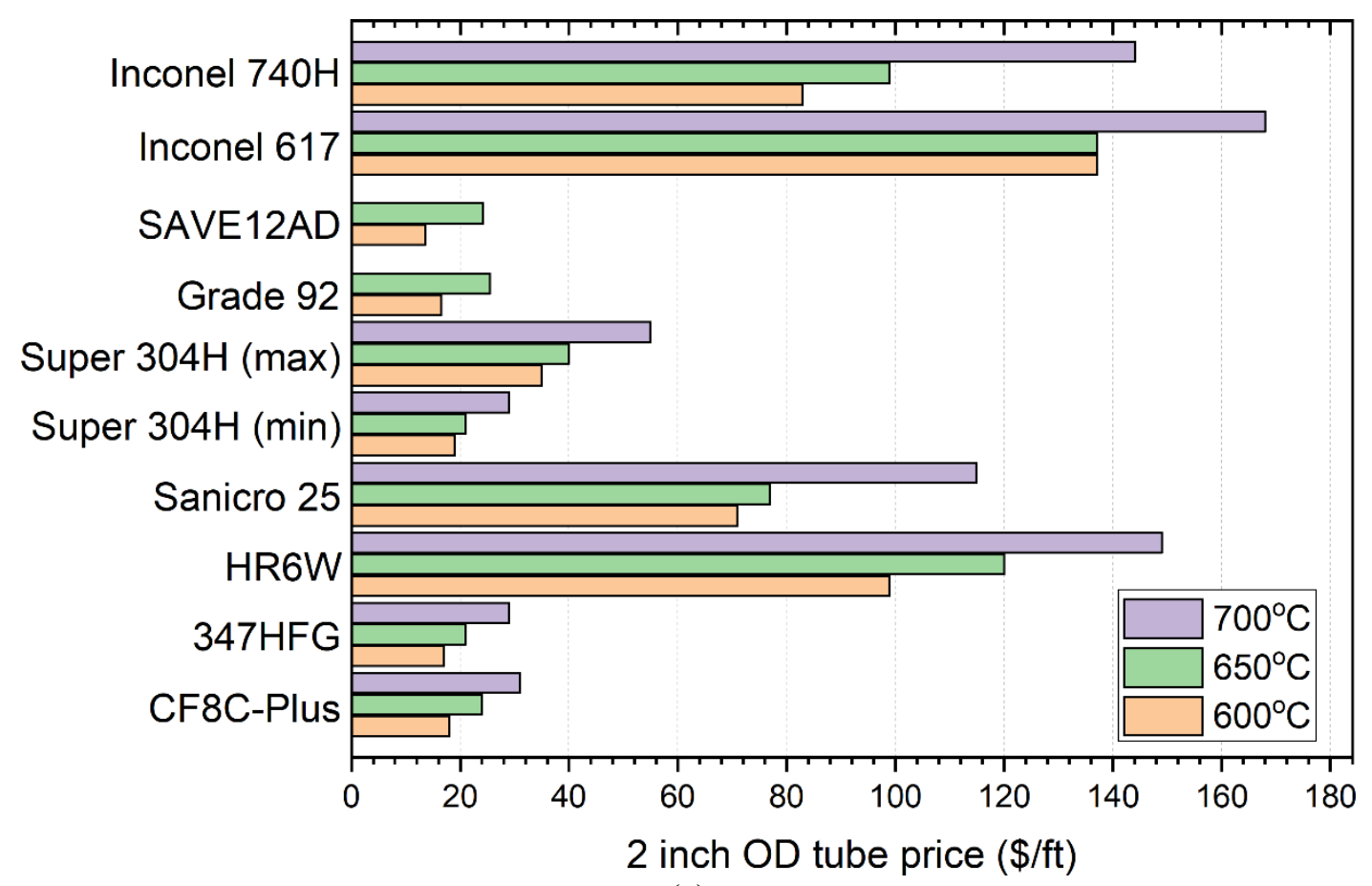

(a) 


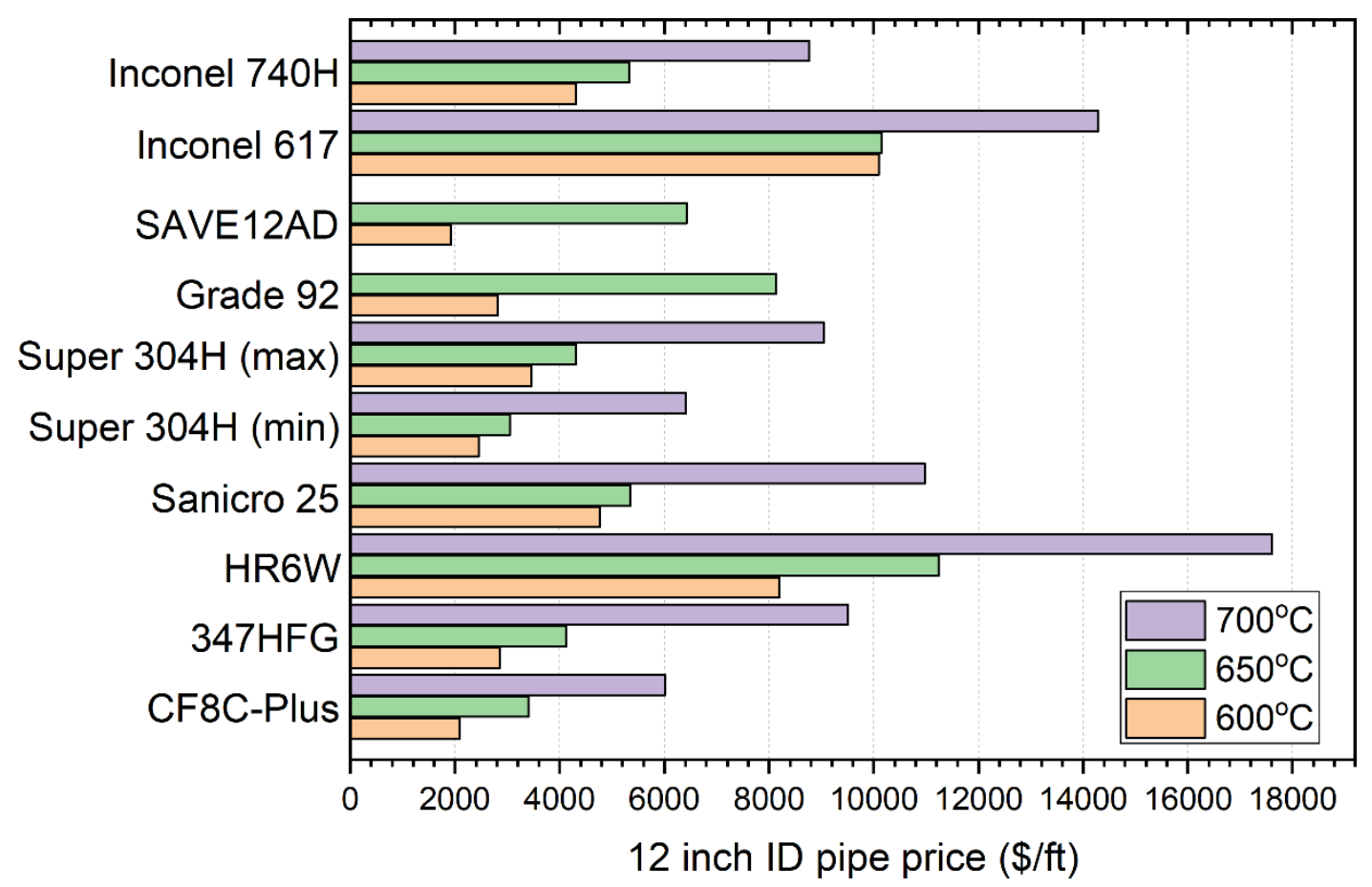

(b)

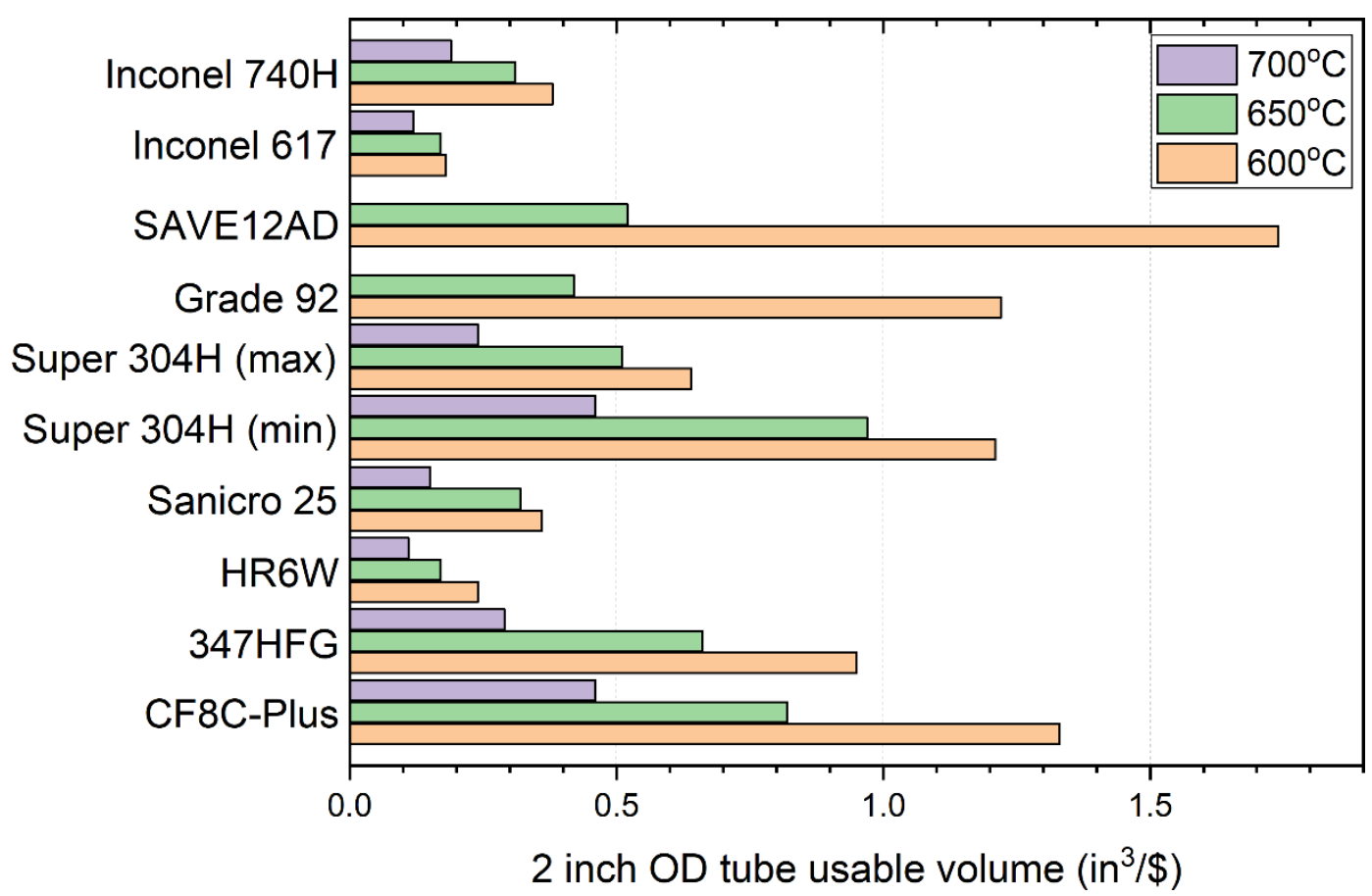

(c)

Fig. 2 Comparison of economy analysis results for AUSC candidate materials: (a) 2-inch OD tube price, (b) 12-inch ID pipe price, and (c) 2-inch OD tube usable volume 


\section{MOIST AIR OXIDATION}

During the typical operation of AUSC power plants, materials will be subjected to high-temperature steam oxidation. It is critical that the candidate materials should have sufficient steam oxidation resistance during the plant operation. In this report, we compare the moist air oxidation (more aggressive environment than the pure steam) rates for CF8C-Plus, 347HFG, Super 304H, and Inconel 617 in the temperature range of $650-760^{\circ} \mathrm{C}$ based on published literature results.

In the work of Dryepondt et al., [15], oxidation tests were performed at $650-800^{\circ} \mathrm{C}$ in air $+10 \%$ vol. $\mathrm{H}_{2} \mathrm{O}$ on CF8C-Plus and its compositional variations. At $650^{\circ} \mathrm{C}$, a stable oxide scaled formed on CF8C-Plus and the thickness of the inner oxide layer was up to $\sim 20 \mu \mathrm{m}$ after $5,000 \mathrm{~h}$ exposure $(<1.4$ mil per year based on parabolic oxidation law). At $700^{\circ} \mathrm{C}, \mathrm{CF} 8 \mathrm{C}$-Plus experienced scale spallation after $\sim 3,000 \mathrm{~h}$ exposure with constant mass loss after then. The inner oxide layer was up to $\sim 20 \mu \mathrm{m}$ after $1000 \mathrm{~h}$ exposure.

Assuming the oxide spallation rate is $20 \mu \mathrm{m}$ per $1000 \mathrm{~h}$, which is a conservative estimate, this translates into 6.9 mil per year moist air oxidation rate. Above $700^{\circ} \mathrm{C}, \mathrm{CF} 8 \mathrm{C}-\mathrm{Plus}$ suffered rapid weight loss due to spallation of Fe-rich oxide nodules. Fig. 3 shows the specimen mass change in moist air environment for CF8C-Plus and its variant steels at $650-750^{\circ} \mathrm{C}$.
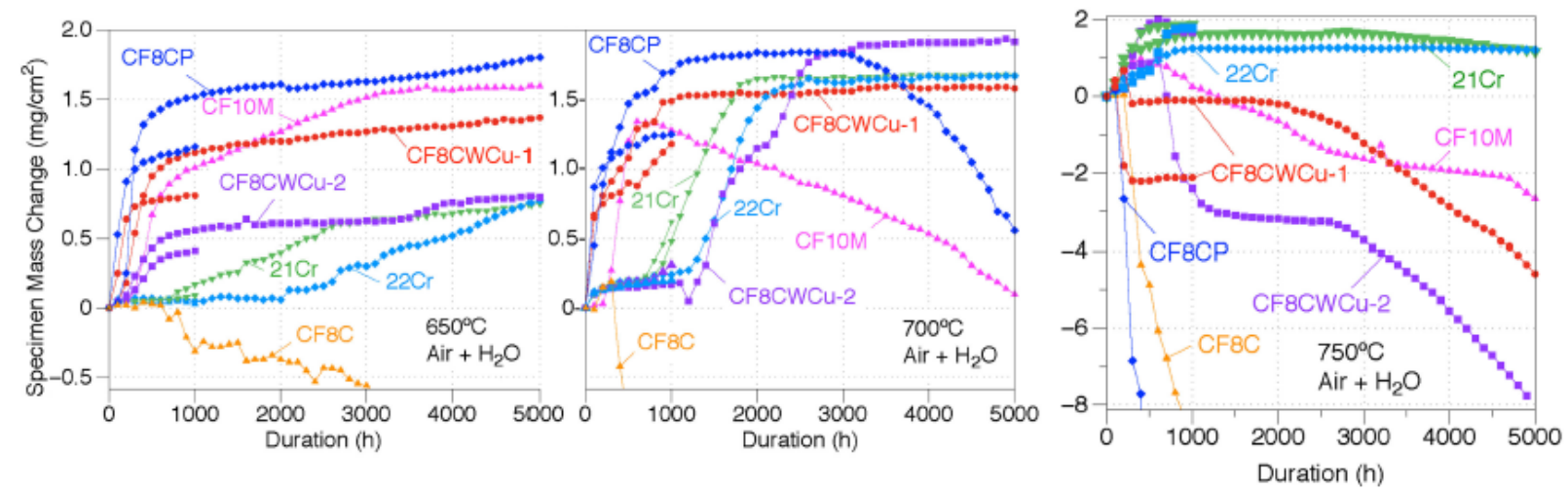

Fig. 3 Specimen mass change in moist air for CF8C-Plus and its variations at $650-750^{\circ} \mathrm{C}$ [15]

Dudziak et al., conducted steam oxidation tests on 347HFG and Super $304 \mathrm{H}$ for $1000 \mathrm{~h}$ at 650 and $700{ }^{\circ} \mathrm{C}$ with three different steam flow rates $(4,16,40 \mathrm{~mm} / \mathrm{s})$ referred to as low, medium, and high flow rates [16]. They found the steam oxidation rate increased with the temperature and steam flow rate. They also concluded Super $304 \mathrm{H}$ had slightly better steam oxidation resistance than $347 \mathrm{HFG}$ at 650 and $700^{\circ} \mathrm{C}$.

A direct comparison for the moist air oxidation performance between CF8C-Plus and 347HFG can be found in the work of Maziasz and Pint [17]. At $700^{\circ} \mathrm{C}$ in air $+10 \%$ vol. $\mathrm{H}_{2} \mathrm{O}$ environment, CF8C-Plus showed reasonable moist air oxidation rate whereas $347 \mathrm{HFG}$ specimen exhibited an apparent mass loss due to spallation of the Fe-rich oxide scale (Fig. 4). Since Super 304H only has slightly better steam oxidation resistance than $347 \mathrm{HFG}$ at $700^{\circ} \mathrm{C}$ [16], it is reasonable to expect that CF8C-Plus should also have better steam oxidation resistance than super $304 \mathrm{H}$ at $700^{\circ} \mathrm{C}$. Indeed, CF8C-Plus has slightly higher $\mathrm{Ni}$ and $\mathrm{Cr}$ contents than both $347 \mathrm{HFG}$ and Super $304 \mathrm{H}$ as shown in Table 1. Based on the findings in [15\& 18], austenitic alloys with high $\mathrm{Cr}$ and $\mathrm{Ni}$ contents are expected to have better steam oxidation performance.

Lastly, Holcomb et al., performed cyclic oxidation experiments of advanced alloys for ultra supercritical systems in humid air (50\% water vapor $+50 \%$ air by volume) at $760^{\circ} \mathrm{C}[19]$. They found Inconel 617 had 
virtually no net mass loss and developed a very thin oxide scale after $2000 \mathrm{~h}$ exposure as shown in Fig. 5. Among all studied materials, Inconel 617 exhibited the best moist air oxidation performance.

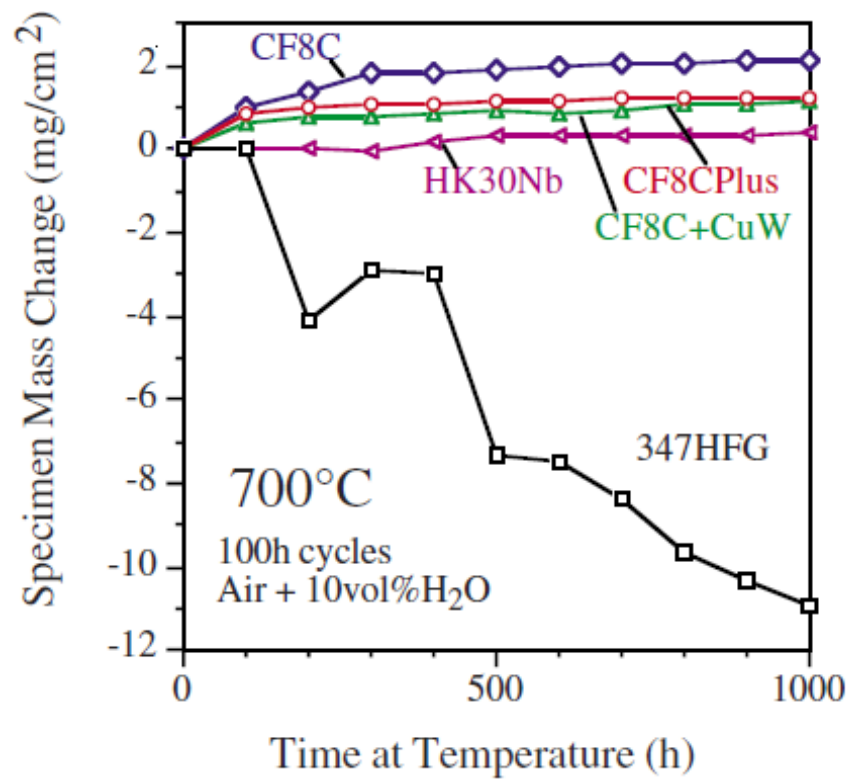

Fig. 4 Comparison of specimen mass change for various stainless steels in humid air at $700^{\circ} \mathrm{C}$ [17]

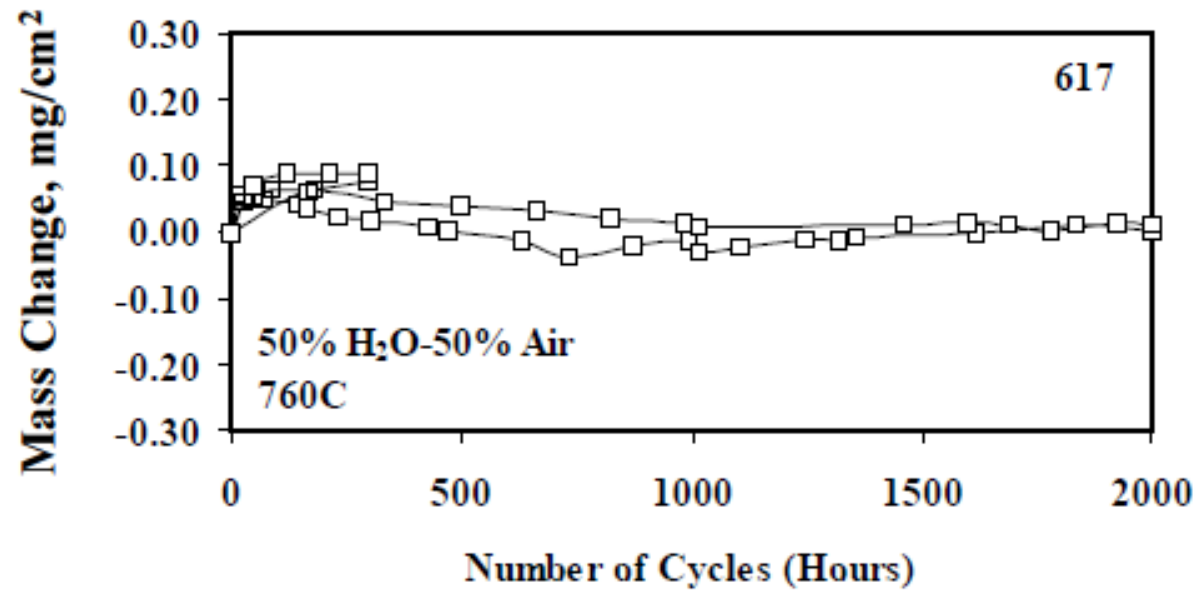

(a)

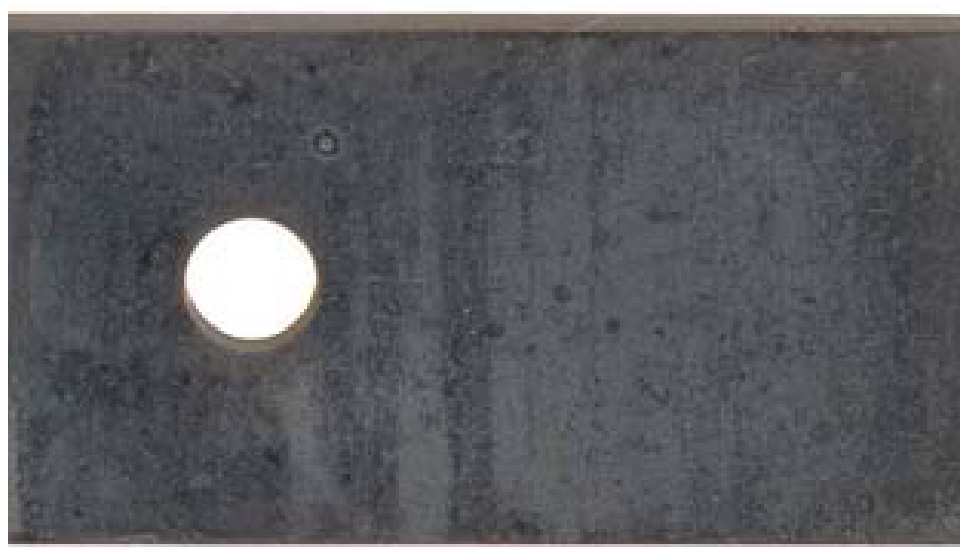

(b) 


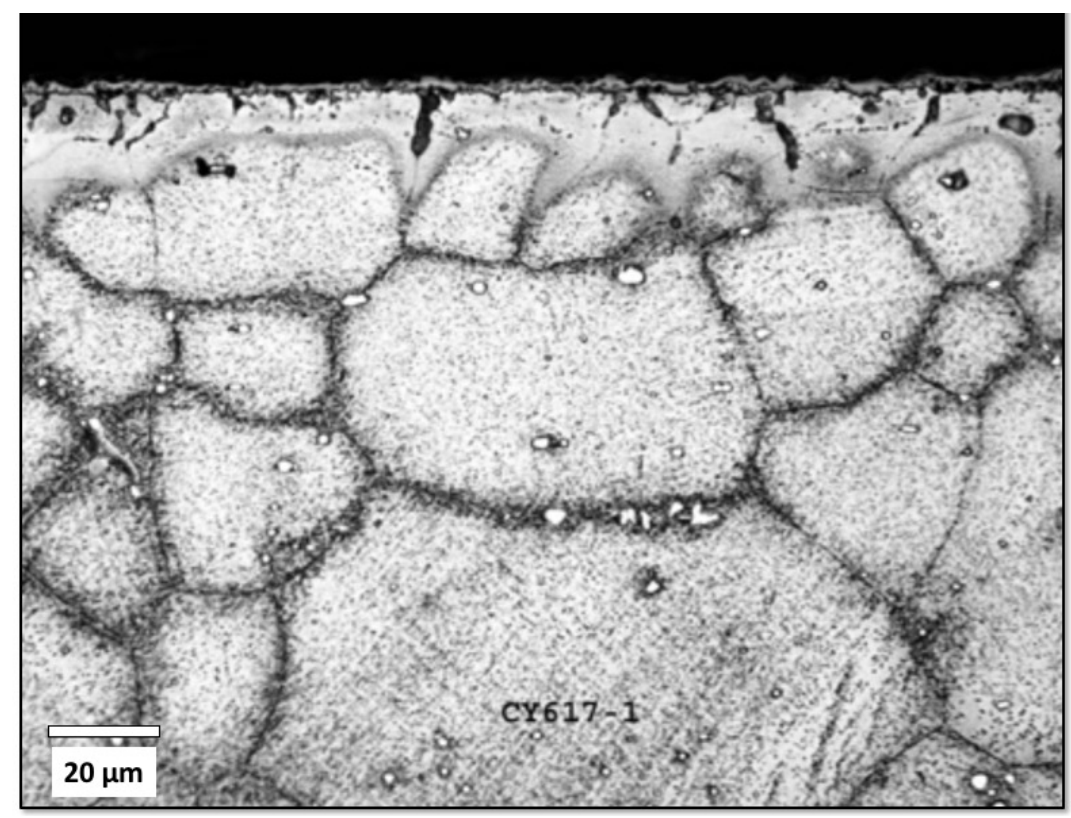

(c)

Fig. 5 Cyclic oxidation results for Inconel 617 at $760^{\circ} \mathrm{C}$ in $50 \% \mathrm{H} 2 \mathrm{O}-50 \%$ air up to $2000 \mathrm{~h}$. (a) Mass change, (b) surface optical microscopy, and (c) cross-sectional metallography [17]

\section{CONCLUSIONS}

This report provides a brief techno-economic analysis for castable stainless steel, CF8C-Plus, and other candidate materials for AUSC applications, including 347HFG, HR6W, Sanicro 25, Super 304H, Grade 92, SAVE12AD, Inconel 617, and Inconel 740H. Overall, CF8C-Plus shows a favorable combination of material costs, creep resistance and moist air oxidation performance for AUSC applications in the temperature range of $600-700^{\circ} \mathrm{C}$.

\section{REFERENCES}

1. Maziasz, P. J., Shingledecker, J. P., Evans, N. D., \& Pollard, M. J. (2008). CF8C-Plus Heat-Resistant Cast Stainless Steel. Advanced Materials and Processes, 166(10), 27.

2. ASM Alloy Center Database.

3. SANDVIK, Sanicro® 25 datasheet.

4. Nippon Steel \& Sumitomo Metal, Seamless steel tubes and pipes for boilers datasheet.

5. Special Metals, Inconel 617 datasheet.

6. Special Metals, Inconel $740 \mathrm{H}$ datasheet.

7. ASTM A336 / A336M-18a, Standard Specification for Alloy Steel Forgings for Pressure and HighTemperature Parts, ASTM International, West Conshohocken, PA, 2018, www.astm.org

8. Hamaguchi, T., Okada, H., Hirata, H., Kurihara, S., Semba, H., \& Yoshizawa, M. (2018). Creep Rupture Strength and Microstructures of SAVE12AD Welded Joints, Nippon Steel \& Sumitomo Metal Technical Report No. 119.

9. Pint, B. A., Wang, H., Maziasz, P. J., Hawkins, C. S., Miller, R. G., Swindeman, R. W., \& Rahoi, D. W. (2014). ASME Code Case Progress for CF8C-Plus Cast Austenitic Stainless Steel. ASME BPV Code Week, August 18-22, 2014, Washington, DC.

10. Li, A., Cedro III, V., \& Conrad, R. K. (2016). Cost Effectiveness of Potential AUSC Alloys. U.S. Department of Energy Mickey Leland Energy Fellowship Program Report, August 5, 2016. 
11. Private communication with Michael Kemmer, MetalTek International, June 2018

12. Private communication with Vito Cedro III, August 2018.

13. Private communication with Vito Cedro III, September 2018.

14. Private communication with Daniel Purdy, September 2018.

15. Dryepondt, S., Pint, B. A., \& Maziasz, P. J. (2015). New Creep-Resistant Cast Alloys with Improved Oxidation Resistance in Water Vapor at $650-800^{\circ}$ C. Frontiers in Materials, 2, 55.

16. Dudziak, T., Łukaszewicz, M., Simms, N., \& Nicholls, J. R. (2015). Steam oxidation of TP347HFG, super $304 \mathrm{H}$ and HR3C-analysis of significance of steam flowrate and specimen surface finish. Corrosion Engineering, Science and Technology, 50(4), 272-282.

17. Maziasz, P. J., \& Pint, B. A. (2011). High-temperature performance of cast CF8C-plus austenitic stainless steel. Journal of Engineering for Gas Turbines and Power, 133(9), 092102.

18. Peraldi, R., \& Pint, B. A. (2004). Effect of $\mathrm{Cr}$ and Ni contents on the oxidation behavior of ferritic and austenitic model alloys in air with water vapor. Oxidation of metals, 61(5-6), 463-483.

19. Holcomb, G. R., Covino Jr, B. S., Bullard, S. J., Ziomek-Moroz, M., \& Alman, D. E. (2005).

Oxidation of alloys for advanced steam turbines (No. DOE/ARC-2005-066). Albany Research Center (ARC), Albany, OR. 